\title{
A Way Forward in Aquariculture/Ornamental Fish Farming
}

\author{
Mahadevi*, S. Felix, B. Ahilan, P. Yuvarajan, V.V. Lakshmi \\ Tamil Nadu Dr. J. Jayalalithaa Fisheries University, Nagapattinam (TN), India \\ *Corresponding author
}

\section{A B S T R A C T}

\begin{tabular}{|l|}
\hline Ke y w o r d s \\
$\begin{array}{l}\text { Aquariculture, } \\
\text { Ornamental fish } \\
\text { farming }\end{array}$ \\
\hline Article Info \\
\hline $\begin{array}{l}\text { Accepted: } \\
\text { 17 June } 2019 \\
\text { Available Online: } \\
\text { 10 July } 2019\end{array}$ \\
\hline
\end{tabular}

\section{Introduction}

The ornamental fish sector is a small but unique and vital part of an international fish trade. Fish keeping has emerged as the second most popular hobby in recent years, next to photography (Sudha and Gokula, 2015). There is a great scope for Aquariculture (Ornamental fish culture) by culturing imported exotic fishes locally, or tapping the resources of indigenous fishes, India not only earns foreign exchange but also enters into the world market of ornamental fishes. The contribution of India to the world ornamental fish trade is only at a tune of US\$ 1.7 million, which is rather sparse considering the vast US $\$ 8$ billion global market growing at an average annual rate of $9 \%$ (Vinayak, 2017). In view of India's richness of fish biodiversity, geographic location and access through air connectivity to the international markets, it wouldn't be an understatement that India has not tapped these resources effectively. The demand for indigenous fishes is high in foreign countries. Our country is bestowed with climatic conditions ideal and conducive to growth, maturation and breeding of many indigenous as well as exotic ornamental fishes but India's share in the global export market is insignificant.

The Western Ghats of India is one among the biodiversity hotspots of the world and one of the richest regions in terms of its biological diversity. The Western Ghats holds rich freshwater fish diversity with about 290 
species belonging to 106 genera, 33 families and 11orders. The Western Ghats also portrays 189 species of endemic fish fauna, belonging to 69 genera, 23 families and 7 orders. About 110 species of fishes reported from the Western Ghats have value in the ornamental market (Dahanukar et al., 2011).

Among the endemics, about 150 species of barbs are of ornamental value, comprising mostly of wild caught varieties. Puntius conchonius (Rosy barb) and Puntius titteye (cherry barb) P. denisonii (Kerala queen), Dawkinsia filamentosa, D. rohani, $P$. sophore, Puntius manipurensis, $P$. pookodensis, $P$. melanostigma, $P$. melanampyx, are the most common barbs in the aquarium industry (Mercy, 2009 and Jacob, 2013). Around 40 species of loaches (Botia sp), native of Thailand, India, Pakistan, China, Bangladesh and some Indonesian Islands has a tremendous market value. Small and lively zebra fish which are native to the Indian peninsular, Sri Lanka, Pakistan, Thailand, Myanmar, Malaysia and Indonesia also fetches a good trade in export market. Danio malabaricus (Pearl Danio), Danio albolineata and Brachydanio rerio (zebra fish) are most popular zebra varities. Brachydanio rerio has high demand which is mainly found in Kerala and Karnataka (MPEDA, 2018). If judicious collection, transportation and marketing of these resources are adopted on a sustainable basis, and this could generate employment opportunities at different levels right from the upstream tribal belts to the urban fish exporting sector. Intense exploitation due to high export demands for most of the beautiful endemic fishes has put it in a state of vulnerable, endangered and even extinct levels. Hence to serve market demand and save biodiversity the best solution is to develop seed production technologies for propagation and revival of valuable endemic fish species.

\section{Materials and Methods}

In order to propagate and enrich the indigenous ornamental fish resources in Western Ghat, the fish species namely, Sahyadria denisonii (Kerala queen) and Dawkinsia filamentosa (Filamentous barb) of Kerala origin were selected for the study. The induced breeding technology was developed for both species under the captivity using the synthetic hormones. The optimum dose of the hormone has been standardised by considering high potentiality at a low dose. Induced breeding technology developed by present research will lend a hand for farmers to generate elevated income by producing these valuable fishes.

\section{Results and Discussion}

The major constraint is lack of awareness regarding the sustainable culture practices, standard breeding protocol and advanced culture practices (Mercy, 2003). The Western Ghats are the gold mine of fish diversity which can be utilized for the improvement of the production. However, these resources have not been managed properly either for its conservation or for sustainable exploitation. The destruction of natural fish biodiversity is increasingly practised by overexploitation of endemic species which has high demand in the external market. Unlawful exploitation of fishes like Sahyadria denisonii, Dawkinsia rohani, Puntius sophore, Puntius carnaticus and many other fishes from southern-Western Ghats are listed under IUCN in vulnerable, endangered and critically endangered categories (Raghavan, 2010 and IUCN red list, 2018).

Development of captive breeding technology is the most possible way to conserve the natural population of commercially important endemic ornamental fishes without affecting the growth of aquariculture sector. 
Advancement in breeding and aquarium technology has added new dimensions in the ornamental fish trade with species diversification. Induced spawning of Puntius titteya (Sundarabharathy et al., 2004), Puntius melanampyx, Garra mullya, Danio malabaricus, Chela fasciata, Nemacheilus triangularis, Nemacheilus semiarmatus and Pristolepis marginata (Mercy et al., 2009), P. sophore (Mahapatra et al., 2010), Puntius pookodensis and Pristolepis marginata (Jacob, 2013) Gonoproktopterus curmuca (Padmakumar et al., 2014), Barbus gonionotus (Siddhwartha Kumar et al., 2014), Puntius manipurensis (Motilan et al., 2014), Puntius conchonius (Sudha and Gokula, 2015) and Dawkinsia rohani (Pandi, 2018) has been developed. Similarly there is large scope for development of hatchery technology for the other commercially important endemic species.

In conclusion, India is blessed with the beautiful natural endemic decorative fishes. Development of captive breeding technology for an ornamental valued fishes could be way forward to increase our contribution to the world ornamental fish production. Captive breeding technology of endemic fishes also leads to the species diversification in the ornamental fish market, reduces the exploitation pressure on natural resources to a considerable level and contributes in the conservation of the natural resources.

\section{References}

Dahanukar, N., Rajeev, R., Anvar, A., Robin, A., Shaji, C. P., 2011. The status and distribution of freshwater fishes of the Western Ghats: In Molur S, Smith KG, Daniel BA and Darwall WRT (Compilers). The Status and Distribution of Freshwater Biodiversity in the Western Ghats, India. 21-48 Cambridge, UK and Gland,
Switzerland: IUCN, and Coimbatore, India: Zoo Outreach Organisation.

IUCN Red list 2018. The list of threatened fauna of India. IUCN India.

Jacob, E., 2013. Studies on the captive breeding and reproductive biology of two indigenous ornamental fishes of the Western Ghats. Ph. D Thesis, Mahatma Gandhi University, Kottayam, India.

Mahapatra, B. K., 2010. Breeding and rearing of indigenous ornamental barbs Puntius shanynius and Puntius sophore of NE India. In proceeding of Golden jubilee National seminar on diversification of aquaculture through locally available fish species. Organised by CIFE, Kolkata centre on 27-28 Aug. 2010.

Mercy, T. V. A. 2003. Status of standardisation of captive breeding and propagation of indigenous ornamental fishes of the Western Ghats. Abstract 10, Book of Abstracts, World Aquaculture Society (WAS) Conference, 2003. Salvador, Brazil

Mercy, T.V.A., Malika, V., Sajan, S., Sahayak, S. 2009. Distribution, reproductive biology and development of captive breeding technology of Puntius denisonii- an indigenous ornamental fish of the Western Ghats of India. Presented in the International conference on Ind-Aquaria, Marine Products Export Development Authority at Calcutta, West Bengal, 1020 February.

Motilan, Y., Bedajit, Y., and Sunitibala, W. 2014. Captive breeding of endangered Barbs Pethia manipurensis (Menon et al., 2000) by oral delivery of gonadotropic signaling molecular analogue WOVA-FH. IJSRP. 4 (1):1-4.

Padmakumar, K. G., Bindu, L., Sreerekha, P. S., Nitta Joseph, Manu, Anuradha Krishnan. P.S., 2014. First report on captive breeding of endemic Red tailed silver shark Gonoproktopterus curmuca 
(Cyprinidae: Hamilton-Buchanan 1807)

Int. J. Res. Fish. Aquacul. 4(4):156-160.

Pandi, 2018. Captive breeding of Dawkinsia rohani and standardization of continuous culture techniques for mass production of copepods (cyclopoids). PG Thesis. Tamil Nadu. Dr. J. Jayalalithaa Fisheries University, India.

Raghavan R. Ornamental fisheries and trade in Kerala, pp. 169-197. In: Benziger A and Sonnenschein L. (eds.). Fish Conservation in Kerala. World Aquariums and Oceans Federation, St. Louis, USA, 2010.

Siddhwartha, K. B., Gupta, N., Haque, M. M., Amin, R., 2014. Embryonic and larval development of silver Barb (Barbodes gonionotus) in a mobile Hatchery under laboratory condition. European Scientific Journal September /SPECIAL/ edition Vol. 3: 258-270.

Sudha, C., Gokula, V., 2015. Induced spawning of rosy barb Puntius conchonius by Natrum muriaticum. IJAPBC. 4(4): 801-804.

Sundarabarathy, T. V., Edirisinghe, U., Dematawewa, C. M. B., 2004. Captive Breeding and Rearing of Fry and Juveniles of Cherry Barb (Puntius titteya Deraniyagala), a 181 Highly Threatened Endemic Fish Species in Sri Lanka. Tropical Agricultural Research. 16:137-149.

Vinayak A. J., 2017. Aquarium trade will be worth ₹ $1,200 \mathrm{cr}$ in a decade. Business Line (The Hindu), 15th May 2017.

\section{How to cite this article:}

Mahadevi, S. Felix, B. Ahilan, P. Yuvarajan and Lakshmi, V.V. 2019. A Way Forward in Aquariculture/Ornamental Fish Farming. Int.J.Curr.Microbiol.App.Sci. 8(07): 2270-2273. doi: https://doi.org/10.20546/ijcmas.2019.807.277 